\title{
MANAGEMENT OF SUSTAINABLE SEAWEED (Kappaphycus alvarezii) AQUACULTURE IN THE CONTEXT OF CLIMATE CHANGE MITIGATION
}

\author{
Erlania* and I Nyoman Radiarta \\ Center for Aquaculture Research and Development, J akarta
}

(Received 12 February 2014; Accepted 24 April 2014)

\begin{abstract}
Seaweed is an important aquaculture commodity that could contribute on climate change mitigation, related to its ability on absorbing $\mathrm{CO}_{2}$, as one of the green house gases, through photosynthesis. This study aimed to analyze seaweed potencies on carbon sequestration in the context of climate change mitigation while still resulting optimum production as primary purpose and to analyze the carrying capacity of Gerupuk Bay in order to manage sustainability of seaweed aquaculture. Seaweed, (Kappaphycus alvarezii) was cultivated with long-line system in Gerupuk Bay, West Nusa Tenggara, during five months for three cultivation cycles. Samplings were conducted at days- 15,30 , and 45 with $\mathrm{CO}_{2}$ absorption rates as main parameters. Water carrying capacity was calculated to determine the ability of Gerupuk Bay waters for supporting development of sustainable seaweed aquaculture. The results showed that absorption rates of $\mathrm{CO}_{2}$ by seaweed ( $\mathrm{K}$. alvarezii) were different at each sampling days of cultivation periods; the highest value was at 10-20 days of cultivation. $\mathrm{CO}_{2}$ absorption analysis resulted based on sampling days of cultivation period could be applied to formulate the strategies for management of sustainable seaweed aquaculture, with optimal production and positively contributed to the environment. However, waters carrying capacity should also be considered as major aspect in the application of seaweed cultivation management, thus it can run continuously without causing conflicts with other interests.
\end{abstract}

KEYWORDS: sustainable aquaculture, seaweed, management, $\mathrm{CO}_{2}$ absorption, carrying capacity, climate change

\section{INTRODUCTION}

Seaweed is one of aquaculture commodity that also plays an important role in environmental quality improvement, related to climate change mitigation. Seaweed as photoautotrophic macroalgae has ability to absorb $\mathrm{CO}_{2}$ that is used in photosynthesis process to form carbohydrate as primary product and oxygen as by- product. $\mathrm{CO}_{2}$ is a colorless, odorless, faintly acidic, very stable, non- reactive, and non- flammable gas that like other greenhouse gases (GHGs), only present in the atmosphere in tiny quantities; by volume less than $0.04 \%$ of all gases in the atmosphere; and the concentration in the atmosphere has reached 382 mg/ L by 2007 (Dawson \& Spannagle, 2009) and was predicted to rise to $450 \mathrm{mg} / \mathrm{L}$ by 2020 if no action is taken (Kraan, 2010). $\mathrm{CO}_{2}$ is the most important anthropogenic GHG that annual emissions have grown between 1970 and 2004

\# Corresponding author. Center for Aquaculture Research and Development Jl. Ragunan 20, Pasar Minggu, Jakarta Selatan 12540, Indonesia. Phone: +62 217805052 E-mail: erlania_elleen@yahoo.com 
by about $80 \%$ from 21 to 38 gigatonnes (Gt), and represented $77 \%$ of total anthropogenic GHG emissions in 2004 (IPCC, 2007). Average global temperatures have increased by $0.76^{\circ} \mathrm{C}$ since 1900, and has led to changes in geophysical and biophysical earth system (Dawson \& Spannagle, 2009). In general, mitigation is aimed at reducing the causes of climate change, in particular the emissions of the gases (Houghton, 2004).

In Indonesia, seaweed is the highest production of aquaculture commodity (DJPB, 2012). Seaweeds have been used for human and animal consumption, sources of phycocolloids, as raw material of cosmaceuticals and nutraceuticals, and also can be used as fertilizers, feed-stuff, and biofuels resources (McHugh, 2003). Large- scale open water cultivations of seaweed have been carried out for decades with optimum production as the main purpose. Seaweed has high productivity as shown by growth rates of this marine macroalgae that far exceed those of terrestrial biomass (Kraan, 2010). Nowadays, seaweed aquaculture activity has more important role than production attainment only.

General evolution of seaweed cultivation has been developed from cultivation activity to produce biomass, shifted to cultivation activity as nutrient bioextraction; that is an environmental management strategy by which nutrients are removed from an aquatic ecosystem through the harvest of enhanced biological production, including the aquaculture of marine algae and/ or suspension- feeding shellfish (Barrington et al., 2009). The cultivation of seaweed can make a beneficial effect in some respects such as nutrient removal and can facilitate polyculture. Seaweed culture is an extensive culture system which relies mostly on a natural nutrient supply (Phillips, 1990; Chopin et al., 2001). More importantly, seaweed cultivation activites have also become carbon sequestration system (Grimsditch, 2011; Grimsditch \& Chung, 2012). Recent study shows that the rate of carbon sequestration based on harvesting biomass of Gracilaria gigas reached up to 90.09 ton $\mathrm{C} / \mathrm{ha} /$ year, almost 335.79\% higher than $\mathrm{K}$. alvarezii that was 20.67 ton C/ ha/ year (Erlania et al., 2013a). However, during the cultivation process of seaweed, there was a difference in the absorption rate of $\mathrm{CO}_{2}$ depending on age of cultivation days. High potency of carbon sequestration of cultured seaweed could be an alterna- tive of sustainable seaweed aquaculture management in context of climate change mitigation. Strategy of seaweed cultivation might be applied based on the highest to the lowest carbon absorption rate of each age of cultivation day. This study aimed to analyze potential of seaweed as carbon sequestration in the context of climate change mitigation while still resulting optimum production as primary purpose and to analyze the carrying capacity of Gerupuk Bay in order to manage sustainability of seaweed aquaculture.

\section{MATERIALS AND METHODS}

\section{Seaweed Cultivation}

The study was conducted in Gerupuk Bay, Central Lombok, West Nusa Tenggara from July- November 2012 (Figure 1). Seaweed (K. alvarezii) was cultivated with long- line system for wide area of 2,500 $\mathrm{m}^{2}$. The long- line systems consist of primary line that were designed to be square shaped, equipped with anchors and buoys at each corner. Secondary line stretched between the primary line; the seeds were bunched with plastic rope to secondary line. The K. alvarezii seeds were obtained from National Seaweed Center, Gerupuk, Central Lombok, West Nusa Tenggara. Duration of cultivation was 135 days with harvesting time every 45 days. The yield from the first period of culture (45 days) was replanted for the next cultivation cycle (second and third periods). $\mathrm{CO}_{2}$ absorption rates by $\mathrm{K}$. alvarezii were analysed on days 15, 30, and 45 for each cultivation cycle.

Estimation of $\mathrm{CO}_{2}$ Absorption Rate and Seaweed Aquaculture Productivity

$\mathrm{CO}_{2}$ absorption (ton $\mathrm{CO}_{2} /$ ha/ year) by seaweed could be estimated based on carbon absorption calculation which is multiplied with $\mathrm{CO}_{2}$ conversion factor. Estimation of carbon absorption by cultivated seaweed calculated based on formulation by Muraoka (2004):

$$
\begin{aligned}
\text { C absorption }= & \text { Total area }(\text { ha }) \times \text { Standing stock } \\
& \times \text { P }- \text { B ratio } \times \text { Carbon content }(\%)
\end{aligned}
$$

Productivity of seaweed aquaculture was calculated based on total yield every period of culture (45 days) that was considered to be one cycle of cultivation. Yield from every cultivation cycle was converted to seaweed farming wide area. 


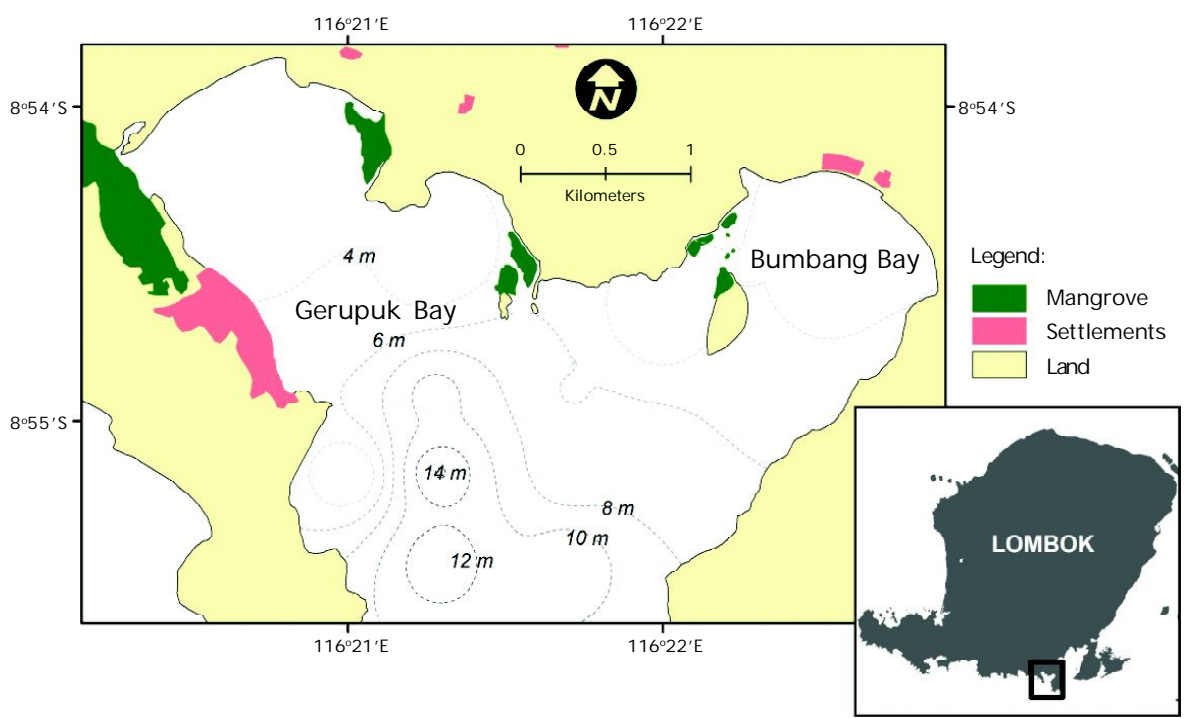

Figure 1. Research site at Gerupuk Bay, Central Lombok, West Nusa Tenggara

\section{Waters Carrying Capacity}

Waters capacity for seaweed aquaculture was defined as an area of water that can be used for seaweed cultivation activities continually, but socially and ecologically will not cause conflicts and coastal ecosystems damage. Calculation of waters capacity for seaweed cultivation with long- line system considered wide area that occupied by long- line unit including space between the units for water circulation. Waters capacity was calculated as follows (Azis, 2011):

$$
\text { Water capacity }(\%)=\frac{L_{2} P_{2}-L_{1} P_{1}}{L_{2} P_{2}} \times 100 \%
$$

where:

$\mathrm{L}_{1}=$ Width of a unit long- line

$L_{2}=$ Suitable width of a unit long- line

$P_{1}=$ Length of a unit long- line

$P_{2}=$ Suitable length of a unit long- line

The method used to calculated waters carrying capacity for seaweed aquaculture was based on the analysis of land suitability (Azis, 2011). Calculation of carrying capacity in Gerupuk Bay involved total suitable wide area for seaweed aquaculture based on feasibility study which was done by Radiarta $\&$ Rasidi (2012). The carrying capacity for seaweed aquaculture was calculated using the formula (Azis, 2011):

$$
\text { Carrying capacity (ha) }=\text { Wa } \times \text { Wc }
$$

where:

$\mathrm{Wa}=$ Suitable wide area (ha)

Wc $=$ Water capacity $(\%)$

Generally, size of long- line units that was used in Gerupuk Bay was 2,500 m² $(50 \mathrm{~m}$ x 50 $\mathrm{m})$. Distance between long- line unit is ideally around $10 \mathrm{~m}$ (Azis, 2011), which is twice of maximum width of the boat width weight- counterbalancing. So, the wide area required for a long- line unit is ideally $4,900 \mathrm{~m}^{2}(70 \mathrm{~m} \times 70 \mathrm{~m})$. Determination of maximum number of cultivation units with long line system which can be supported by the waters capacity can be calculated using the formula (Azis, 2011):

$$
\text { Number of long- line unit }=\frac{C}{A}
$$

where:

$\mathrm{C}=$ Carrying capacity (ha)

$A=$ Ideal wide area for a long- line unit (ha/ unit)

\section{Data Analysis}

The data collected was analyzed using simple statistical methods of descriptive statistics (mean and standard deviation) and the result showed in tables and graphs. The relationship between amount of $\mathrm{CO}_{2}$ absorbed with seaweed aquaculture productivity was calculated with linier regression method. 


\section{RESULTS AND DISCUSSION}

\section{Carbon $\left(\mathrm{CO}_{2}\right)$ Sequestration for Mana- gement of Seaweed Aquaculture Deve- lopment}

$\mathrm{CO}_{2}$ absorption rate by seaweed ( $\mathrm{K}$. alvarezii) aquaculture was different at each age of cultivation day (Figure 2). Generally, the highest rate of $\mathrm{CO}_{2}$ absorption was found in the age of 15 days; further decreased at day- 30, then increased again at the age of 45 days, thus continued from the first period to the second periods of culture. While in the third periods of culture, the rate of $\mathrm{CO}_{2}$ absorption at day- 45 remained decreased (Figure 2 ).

Table 1 shows the large amounts of $\mathrm{CO}_{2}$ absorbed by seaweed proportional to the productivity of seaweed aquaculture. The productivity of the first and second periods of seaweed cultivation was relatively higher com- pared to the third period of culture. Likewise, the rate of $\mathrm{CO}_{2}$ absorption was also higher in the first and second periods compared to the third period. Model of the relationship between the rate of $\mathrm{CO}_{2}$ absorption and seaweed aquaculture productivity following the equation $y$ $=0.0202 x+0,006 . R^{2}$ value of the model was 0.9225 which showed strong relationship between the rate of carbon absorption and seaweed farming productivity.

The differences in productivity of seaweed aquaculture at different periods of cultivation could also indicate that there were differences in the environmental and climate conditions of each period of cultivation (Radiarta et al., 2013). Thus, it could be estimated that the environmental conditions in Gerupuk Bay were relatively suitable to support cultivation of seaweed K. alvarezii in the first and the second periods of culture which was shown by

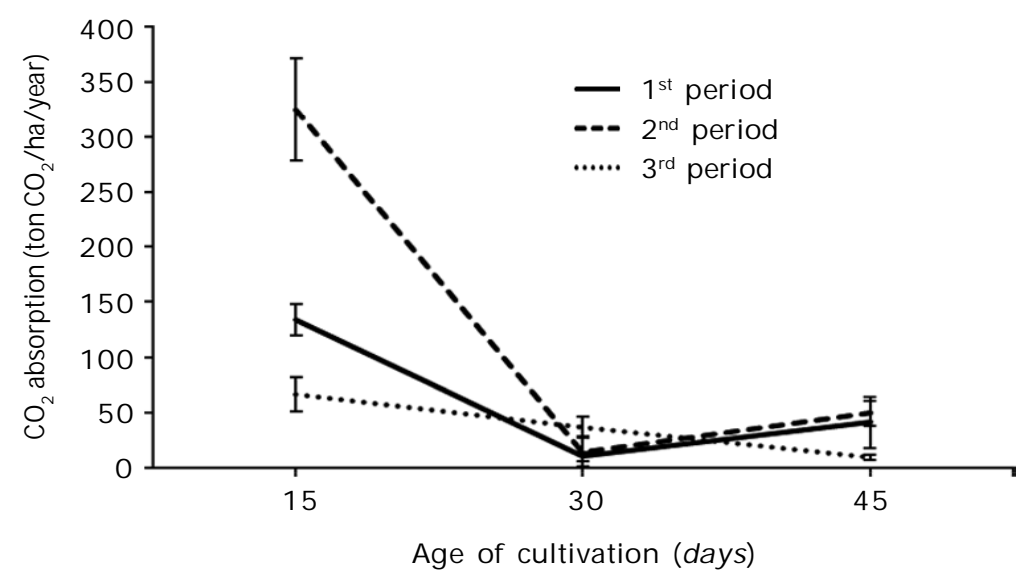

Figure 2. Different levels of $\mathrm{CO}_{2}$ sequestration rate (ton $\mathrm{CO}_{2} /$ ha/ year) by seaweed at different age of cultivation days in Gerupuk Bay, Central Lombok

Table 1. The amount of $\mathrm{CO}_{2}$ absorbed by seaweed aquaculture in Gerupuk Bay, Central Lombok

\begin{tabular}{ccc}
\hline $\begin{array}{c}\text { Periods of } \\
\text { culture }\end{array}$ & $\begin{array}{c}\mathbf{C O}_{2} \text { absorbed } \\
\text { (ton } \mathbf{C O}_{\mathbf{2}} \text { /ton yield) }\end{array}$ & $\begin{array}{c}\text { Seaweed aquaculture } \\
\text { productivity (ton/ ha/ year) }\end{array}$ \\
\hline $1^{\text {st }}$ period & 1.32 & 56.64 \\
$2^{\text {nd }}$ period & 1.76 & 89.60 \\
$3^{\text {rd }}$ period & 0.70 & 39.68 \\
\hline Model : & $y=0.0202 x+0.006$ & \\
$\mathbf{R}^{\mathbf{2}:}$ & 0.9225 & \\
\hline
\end{tabular}


high seaweed productivity. In the third period of cultivation, the quality of marine environment in the location was not optimum condition for seaweed $\mathrm{K}$. alvarezii cultivation, so that productivity was relatively lower than the previous periods of culture (Table 1 ).

The most effective ways to reduce $\mathrm{CO}_{2}$ emissions are to improve energy efficiency of each economic sector and to lessen destruction of tropical and temperate forests around the world (Ritschard, 1992). However, this option may not be fully achieved technically and economically, because of the presence of various barriers both social and political. Ritschard (1992) also stated that the most practical of the innovations is to increase $\mathrm{CO}_{2}$ sinks through photosynthesis, including increased $C$ storage in standing tree biomass, substitution of fossil fuels with biofuels, increased soil $C$ sequestration, and increased ocean primary productivity. However, from each of these methods there are still remained unanswered questions about the technical and economic feasibility, as well as the environment consequences that may be resulted.

Through seaweed aquaculture activity, technical, and economic feasibility could be achieved. Seaweed aquaculture could contribute not only as a source of livelihood for coastal communities but also plays an important role to control environment quality, especially in decreasing of $\mathrm{CO}_{2}$ concentration from the atmosphere (Muraoka, 2004; Kaladharan et al., 2009). The differences of $\mathrm{CO}_{2}$ absorption rates in different age of seaweed cultivation day, can be used as an alternative in determining the strategy of sustainable seaweed aquaculture management. The highest rate of $\mathrm{CO}_{2}$ absorption in the age of 15 days, may also indicate the highest growth rate of seaweed at this age of cultivation. This condition can be applied in the management of seaweed aquaculture, particularly to develop seaweed nurseries. At the age interval we can make rejuvenation from the cultivated seaweed, by cutting the secondary thallus to be replanted for seed production then be used as seed supplier for growing stage. Thus, seaweed aquaculture activities can be more effective in absorbing $\mathrm{CO}_{2}$ from the environment, and can play even greater role in the process of climate change mitigation (Erlania et al., 2013b). Many factors could influence the success of seaweed aquaculture, not only land suitability and cultivation technology, but also suffi- ciency, quality, and continuity of seed supply (Parenrengi, 2011). Therefore, seaweed nursery is an important factor for seaweed aquaculture sustainability development. Seaweed nurseries development as a part of seaweed aquaculture process will contribute to decrease $\mathrm{CO}_{2}$ from the environment.

$\mathrm{CO}_{2}$ absorption rate tended to decrease until the lowest rate at the age of 30 days, and then to increase again at the age of 45 days for the first and second periods of cultivation (Erlania \& Radiarta, 2014). The environmental conditions during these periods were relatively close to the optimum for seaweed cultivation (Erlania \& Radiarta, 2014; Radiarta et al., 2013), thus it could be considered as the natural cycle of the species K. alvarezii cultivated in coastal waters with long line system. This cycle was in accordance with the cultivation practice by seaweed farmers that determined the duration of $\mathrm{K}$. alvarezii cultivation for one cycle, i.e. one cycle is conducted for 45 days. At day 45 , cultivated seaweed were harvested and partly replanted. Vegetative regeneration is an effective means for propagation of K. alvarezii. Increasing of the $\mathrm{CO}_{2}$ absorption rate on day- 45 also indicated increasing of seaweed growth rate at the same time.

\section{Waters Carrying Capacity for Sustainable Seaweed Aquaculture}

Carrying capacity of area indicated the maximum capacity of wide area to support farming activities continuously without causing degradation, both social and biophysical environment (Azis, 2011). Carrying capacity is an important factor for maintaining sustainability of seaweed aquaculture activities as well as other food production systems (Zamroni \& Yamao, 2011). Feasibility study by Radiarta \& Rasidi (2012) reported that available area of Gerupuk Bay suitable for seaweed aquaculture was 322 ha (Table 2). Carrying capacity for seaweed aquaculture activities in Gerupuk Bay using water capacity approach was $157.71 \mathrm{ha}$, and the number of long- line units which can be supported for seaweed aquaculture activities were 321 units (Table 2 ).

Water quality is also an important factor which determines the success of seaweed cultivation. Water quality is one of main parameters in the analysis of site suitability for seaweed cultivation, in addition to socio- economic, institutional, and infrastructure availabil- 
Indonesian Aquaculture Journal Vol. 9 No. 1, 2014

Table 2. Characteristic of Gerupuk Bay, Central Lombok to support sustainable seaweed aquaculture

\begin{tabular}{lcr}
\hline \multicolumn{1}{c}{ Characters } & Units & Values \\
\hline Suitable wide area (Radiarta \& Rasidi, 2012) & ha & 322.00 \\
Ideal wide area for a long line unit & ha & 0.49 \\
Waters capacity & $\%$ & 48.98 \\
Carrying c apacity & ha & 157.71 \\
Number of long line units & Units & 321.00 \\
\hline
\end{tabular}

ity factors. Furthermore, the results of site suitability analysis used as a basis for determining the water carrying capacity for seaweed aquaculture (Azis, 2011). If seaweed cultivation activities are conducted beyond the waters carrying capacity, the seaweed aquaculture will not be sustained. Moreover, the expected positive contribution to the environment, especially carbon and nutrient absorption from the water will become inefficient.

\section{Seaweed Aquaculture in Context of Climate Change Mitigation}

Great potency of seaweed on carbon sequestration makes the seaweed aquaculture becomes a very important activity that should be more developed. Figure 3 shows the $\mathrm{CO}_{2}$ sequestration rate by several seaweed species under different conditions: natural and farming. Some natural seaweed species could absorb 3.26- 118.73 ton $\mathrm{CO}_{2} / \mathrm{ha} /$ year (Muraoka, 2004), but the cultured species showed higher; 75.79-330.32 ton $\mathrm{CO}_{2} /$ ha/ year (Erlania et al., 2013a). K. alvarezii that was used in this study could absorb 27.35- 158.40 ton $\mathrm{CO}_{2} / \mathrm{ha}$ / year, that were different at each culture periods (Figure 3). Carbon sequestration capability of each seaweed species could become a consideration for developing seaweed aquaculture activity. Gracilaria gigas and Kappaphycus alvarezii are two potential species that have been cultivated not only with high economic value, but also with high capability in carbon sequestration (Erlania et al., 2013a).

Indonesia has a total of about 1.38 million ha potency of seaweed aquaculture area (MMAF- JICA, 2011). If the potential areas were used based on the carrying capacity $(48.98 \%)$,

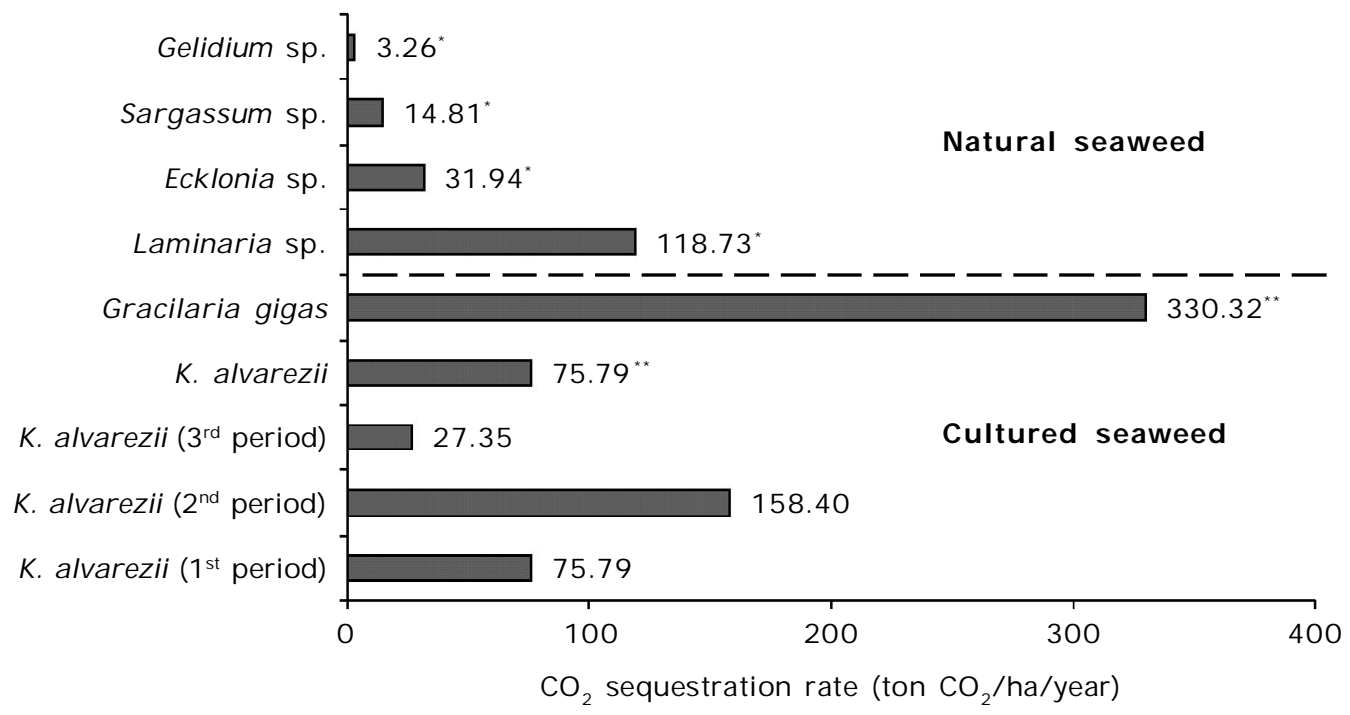

Figure 3. $\mathrm{CO}_{2}$ sequestration rate by different seaweed species under natural and cultured condition (* Muraoka, 2004; ${ }^{* *}$ Erlania et al., 2013a) 
then nationally seaweed aquaculture could contribute in climate change mitigation through carbon sequestration attained to 675.92 ton $\mathrm{CO}_{2}$ / year. Developing sustainable seaweed aquaculture in Indonesia could be conducted not only in line with increasing national seaweed production, but also to improve environmental condition. The more extensive seaweed cultivation area, the greater the carbon that can be absorbed, thus it could give positive impact to the climate change mitigation.

\section{CONCLUSIONS}

The total yield of seaweed aquaculture could simply describe the amount of $\mathrm{CO}_{2} \mathrm{ab}$ sorbed by seaweed cultivation. $\mathrm{CO}_{2}$ absorption analysis resulted based on cultivation periods could be applied to compose an alternative strategy for management of sustainable seaweed aquaculture, even with optimal production and positive contribution to the environment. Gerupuk Bay could support 321 units of long- line for sustainable seaweed cultivation based on its 157.71 ha of carrying capacity. Waters carrying capacity should remain as a major consideration to manage seaweed aquaculture, thus it can run continuously without causing conflicts with other interests. Cultured seaweed shows high capability in carbon sequestration from the environment. Thus, sustainable seaweed aquaculture activity will be more efficient for production and environmental quality improvement, including climate change mitigation.

\section{ACKNOWLEDGEMENT}

We acknowledge the National Seaweed Center, Gerupuk, Central Lombok, West Nusa Tenggara. We greatly appreciate the field assistance by Rasidi, Buntaran, Rusman, and Seme. This project was financed by the Goverment of Indonesia through DIPA 2012.

\section{REFERENCES}

Azis, H.Y. 2011. Optimasi pengelolaan sumberdaya rumput laut di Kabupaten Bantaeng Provinsi Sulawesi Selatan. Sekolah Pascasarjana, Institut Pertanian Bogor. Bogor, 163 pp.

Barrington, K., Chopin, T., \& Robinson, S. 2009. Integrated multi- trophic aquaculture (IMTA) in marine temperate waters. In Soto, D. (Ed.), Integrated mariculture: a global review. FAO Fisheries and Aquaculture Technical Paper. No. 529. Rome, p. 7- 46.
Chopin, T., Buschmann, A.H., \&Haling, C. 2001. Integrating seaweed into marine aquaculture systems: a key toward sustainability. J. Phycol., 37: 975- 986.

Dawson, B. \& Spannagle, M. 2009. The complete guide to climate change. Routledge. New York, 426 pp.

Direktorat Jenderal Perikanan Budidaya [DJPB]. 2012. Statistik perikanan budidaya Indonesia 2011. Kementerian Kelautan dan Perikanan. 116 pp.

Erlania, Nirmala, K., \& Soelistyowati, D. $2013 a$. Penyerapan karbon pada budidaya rumput laut Kappaphycus alvarezii dan Gracilaria gigas di perairan Teluk Gerupuk, Lombok Tengah, Nusa Tenggara Barat. J. Ris. Akuakultur, 8(2): 287- 297.

Erlania, Radiarta, I N., \&Sugama, K. 2013b. Peran budidaya rumput laut terhadap penyerapan karbon dan mitigasi perubahan iklim. Analisis Kebijakan Pembangunan Perikanan Budidaya. p. 11- 20.

Erlania \& Radiarta, I N. 2014. Perbedaan siklus tanam budidaya rumput laut, Kappaphycus alvarezii, terhadap variabilitas tingkat serapan karbon. J. Ris. Akuakultur, 9(1): 111124.

Grimsditch, G. \& Chung, I.K. 2012. Yeosu Workshop on "Coastal Blue Carbon." PICESPress, 20(2): 18- 20.

Grimsditch, G. 2011. Options for blue carbon within the international climate change framework. Sustainable Development Law \& Policy, 11(2): 22- 24.

Houghton, J. 2004. Global warming: The complete briefing. Third Edition. Cambridge University Press. New York, 351 pp.

Intergovernmental Panel on Climate Change [IPCC]. 2007. Climate change 2007: synthesis report. In Allali, A., Bojariu, R., Diaz, S., Elgizouli, I., Griggs, D., Hawkins, D., Hohmeyer, O., Jallow, B.P., Kajfez- Bogataj, L., Leary, N., Lee, H., \& Wratt, D. (Eds. ), The Working Group Contributions to the Fourth Assessment Report. IPCC Plenary XXVII, Valencia, Spain, 12- 17 November 2007. 73 pp.

Kaladharan, P., Veena, S., \& Vivekanandan, E. 2009. Carbon sequestration by a few marine algae: observation and projection. Journal of the Marine Biological Association of India, 51(1): 107- 110.

Kraan, S. 2010. Mass- cultivation of carbohydrate rich macroalgae, a possible solution for sustainable biofuel production. Mitig. Adapt. Strateg. Glob. Change, 18: 27-46. 
McHugh, D.J. 2003. A Guide to the Seaweed Industry. FAO Fisheries Technical Paper No. 441. Food and Agricultural Organization. 106 pp.

Ministry of Marine Affairs and Fisheries- Japan International Cooperation Agency [MMAF-JICA]. 2011. Indonesian Fisheries Book 2011. Co- operation between Ministry of Marine Affair and Fisheries (MMAF) Japan International Cooperation Agency (IICA). 84 pp.

Muraoka, D. 2004. Seaweed resources as a source of carbon fixation. Bull. Fish. Res. Agen. Supplement, 1: 59- 63.

Parenrengi, A., Rachmansyah, Suryati, E. 2011. Budidaya Rumput Laut Penghasil Karaginan (Karaginofit). Edisi Revisi. Balai Riset Perikanan Budidaya Air Payau, Badan Penelitian dan Pengembangan Kelautan dan Perikanan, Kementerian Kelautan dan Perikanan, Jakarta, 54 hal.

Phillips, M.J. 1990. Environmental aspects of seaweed culture. Technical Resource Papers Regional Workshop on The Culture and Utilization of Seaweed Volume II. 2731 August 1990. FAO. Diunduh pada bulan Juni 2014 dari http:/ / www.fao.org/ docrep/ field/ 003/ab728e/ AB728E05.htm

Radiarta, I N., Erlania, \& Rusman. 2013. Pengaruh iklim terhadap musim tanam rumput laut, Kappaphycus alvarezii, di Teluk Gerupuk, Kabupaten Lombok Tengah, Nusa Tenggara Barat. J. Ris. Akuakultur, 8(3): 453464.

Radiarta, I N. \& Rasidi. 2012. Analisa spasial kondisi kualitas perairan untuk mendukung budidaya rumput laut di Teluk Gerupuk Kabupaten Lombok Tengah Provinsi Nusa Tenggara Barat. Proceeding of Seminar Nasional Perikanan Indonesia. Sekolah Tinggi Perikanan. Jakarta, p. 88- 94.

Ritschard, R. L. 1992. Marine algae as a $\mathrm{CO}_{2}$ sink. Water, Air, and Soil Pollution, 64: 289- 303.

Zamroni, A. \&Yamao, M. 2011. Coastal resource management: fishermen's perceptions of seaweed farming in Indonesia. World Academy of Science, Engineering and Technology, 60: 32- 38 . 